\title{
Thrombosis in Autoimmune Diseases: A Role for Immunosuppressive Treatments?
}

\author{
Elena Silvestri, MD, $\mathrm{PhD}^{1,2}$ Antonella Scalera, $\mathrm{MD}^{3}$ Giacomo Emmi, MD, $\mathrm{PhD}^{1,2}$ \\ Danilo Squatrito, $\mathrm{MD}^{1,2}$ Lucia Ciucciarelli, MD ${ }^{1}$ Caterina Cenci, $\mathrm{MD}^{2}$ Carlo Tamburini, $\mathrm{MD}^{2}$ \\ Lorenzo Emmi, MD² Giovanni Di Minno, MD ${ }^{3}$ Domenico Prisco, MD ${ }^{1,2}$
}

${ }^{1}$ Department of Experimental and Clinical Medicine, University of Florence, Florence, Italy

2 SOD Interdisciplinary Internal Medicine, Center for Autoimmune Systemic Diseases-Behçet Center and Lupus Clinic-AOU Careggi Hospital of Florence, Florence, Italy

${ }^{3}$ Department of Clinical Medicine and Surgery, Federico II University

Medical School of Naples, Naples, Italy

\begin{abstract}
Address for correspondence Elena Silvestri, MD, PhD, Department of Experimental and Clinical Medicine, University of Florence, L.go G. Brambilla, 3, Florence, 50134, Italy (e-mail: benedetta.s@tin.it).
\end{abstract}

Semin Thromb Hemost

\begin{abstract}
Keywords

- thrombosis

- immunosuppressive drugs

- autoimmune disease

Autoimmune diseases are not infrequently associated with arterial or venous thrombotic events. Chronic inflammation and immune system impairment are considered the main pathogenetic mechanisms. Some of the drugs used in the treatment of such diseases have been associated with an increased risk of thrombosis. On the contrary, their anti-inflammatory and immune modulator activity could correct some mechanisms leading to thrombosis. In this review, recent evidence available on this topic is examined. There is a lack of adequate studies, but available evidence suggests that glucocorticoids and high-dose immunoglobulins are associated with an increased incidence of venous thromboembolism. Although available data do not allow drawing definite conclusions and more data are needed from future studies and registries, physicians should be aware of these associations.
\end{abstract}

A close relationship exists between systemic inflammation and thrombosis, so that patients with autoimmune diseases may have an increased risk of thrombosis. ${ }^{1}$ The major components involved in the pathogenesis of thrombosis are endothelial damage, coagulation cascade activation, fibrinolytic system impairment, platelet activation, and blood flow alterations. However, the immune system may be also involved in the thrombotic process, and inflammation is a crucial thrombogenic factor. ${ }^{2,3}$ The coagulation system interacts with the inflammatory pathway, leading to the activation of immune cells, as leukocytes and macrophages. The production of proinflammatory cytokines and chemokines may stimulate and modulate endothelial function and blood coagulation. ${ }^{4}$

Several autoimmune disorders are characterized by an increased risk of cardiovascular disease (CVD) and venous thromboembolism (VTE), and these vascular complications have a serious impact on the outcome of patients affected by autoimmune rheumatic disease. ${ }^{5}$ Mechanisms involved in thrombogenesis are varied and remain to be fully understood. Traditional Framingham cardiovascular risk factors probably contribute to atherosclerotic process, but they cannot thoroughly account for the enhanced risk of thrombotic events in these patients, and chronic inflammatory activity seems to be the pivotal risk factor for thrombotic events. ${ }^{6}$ Accelerated atherosclerosis, promoted by the persistent inflammatory activity, is the main feature of several diseases, such as rheumatoid arthritis (RA) ${ }^{7}$ and systemic lupus erythematosus (SLE). ${ }^{8}$ Arterial thrombosis is the most common manifestation, and may present as coronary, cerebrovascular, or peripheral vascular events. VTE, particularly in SLE patients, occurs especially in the presence of antiphospholipid
Issue Theme Editorial Compilation II; Guest Editors: Emmanuel J. Favaloro, PhD, FFSc (RCPA), and Giuseppe Lippi, MD. 
antibodies. ${ }^{9}$ Urowitz et al ${ }^{10}$ described the mortality pattern in SLE patients, with an early peak in the first three years after diagnosis, due to active disease and the degree of organ involvement. The second peak occurs later, after 4 to 20 years, and is related to CVD. According to epidemiological data, nearly all SLE subjects over 65 years develop carotid plaques. $^{11}$

Several proinflammatory components of immune system may act together, thus contributing to the prothrombotic state and progressive atherosclerotic process. In the arterial wall of SLE patients, under a chronic inflammatory condition, an intense inflammatory migration and infiltration of activated lymphocytes and monocytes has been observed along with an upregulation of endothelial adhesion molecules, for example, vascular cell adhesion molecule 1, intercellular adhesion molecule 1 , E-selectin, ${ }^{12,13}$ and proinflammatory cytokines, such as interferon (IFN), tumor necrosis factor $\alpha$ $(\mathrm{TNF}-\alpha)$, and interleukin-1 (IL-1). ${ }^{14}$ High levels of reactive oxygen species, proinflammatory, and oxidized low-density lipoproteins and foam cells are also involved in the initiation and progression of atherosclerosis. Increased endothelial cell apoptosis and low levels of circulating endothelial progenitor cells may contribute to vascular damage. Low-density granulocytes, proinflammatory high-density lipoproteins, neutrophil extracellular traps, matrix metalloproteinase, autoantibodies, such as antiphospholipid antibodies (APL), anti-oxidized low-density lipoprotein antibodies, and immune complexes might also trigger thrombogenesis in SLE patients. ${ }^{15}$ Similar inflammatory events are involved in atherosclerosis development process associated with RA, including $\mathrm{T}$ and $\mathrm{B}$ cells, proinflammatory cytokines (TNF- $\alpha$, IL-1, IL-6, IFN- $\gamma$ ), matrix metalloproteinase, autoantibodies, proteases, and adipokines (adiponectin, leptin). ${ }^{16}$

There is strong evidence that thrombotic events may occur also in systemic vasculitis. ${ }^{17}$ Both arterial and venous thrombosis represent a common vascular manifestation of Behçet syndrome (BS). Vascular involvement was recently added to the international criteria for BS. ${ }^{18}$ Nevertheless, it should be noted that anti-neutrophil cytoplasmic antibody (ANCA)associated vasculitis (AAV) and large-vessel vasculitis (LVV) have also been associated with an increased susceptibility to thrombotic complications. ${ }^{19}$ VTE is the main thrombotic event in systemic vasculitis, especially during active phases of disease. Arterial thrombosis is less common, and an increased risk of CVD has been mostly reported in giant cell arteritis. The pathophysiology of thrombosis in vasculitis is poorly known. The cooperation of inflammatory and coagulation pathways has been implicated, with endothelial cell dysfunction seemingly becoming the prominent feature. The main mechanisms involved in the cross talk between inflammation and thrombosis in vasculitis include the release of cytokines (TNF- $\alpha$, IL-6, IL-1) and chemokines, along with pathologic activation of leukocytes, neutrophils, endothelial cells, and platelets. Moreover, most studies have shown procoagulant endothelial abnormalities such as elevated levels of tissue factor or enhanced adhesion molecules and vascular endothelial growth factor expression. Deficiencies of antithrombin, protein $\mathrm{C}$, and protein $\mathrm{S}$, along with defects in fibrinolysis, might contribute to the development of thrombotic events in these patients. Microparticles, neutrophil extracellular traps, and antiendothelial cell antibodies have been described as a possible link between immune response and endothelial dysfunction in BS as well as in AAV and $\operatorname{LVV}^{17,20}$

The characteristic feature of thrombotic events in connective tissue diseases and systemic vasculitis entails deregulation of immune system, with inflammatory activity as the major risk factor. Here, disease activity control, through antiinflammatory therapy, is necessary to prevent and treat thrombosis in these patients. The European League Against Rheumatism (EULAR) strategies for prevention and management of atherosclerotic disease in RA include immunosuppressive agents and an aggressive approach to traditional cardiovascular risk factors by statins, angiotensin-convertingenzyme inhibitors, angiotensin-II blockers, and lifestyle changes. ${ }^{21}$ Furthermore, EULAR currently suggests immunosuppressive drugs as first-line treatment for vascular thrombosis in BS patients, and the successful use of anti-TNF- $\alpha$ antibodies has been increasingly reported, thus underlining the key role of inflammation in these thrombotic events. ${ }^{22}$

The beneficial effect of an aggressive immunosuppressive treatment in the management of thrombotic complications has been growing over the past years, and it is well known that treatment of the inflammatory process contributes to improved thrombotic outcomes in autoimmune diseases. However, in recent years, the association between thrombotic events and the administration of antirheumatic drugs has been observed and several efforts have been made to elucidate the true value of these observations as well as the possible pathogenetic mechanisms. The importance of a correct use of immunosuppressive therapies in autoimmune disease patients with vascular complications is becoming a crucial topic. Glucocorticoids, antimalarial drugs, immunosuppressive and biologic agents, such as antibody anti-CD20, TNF blockers, and intravenous immunoglobulin (IVIg) therapy are the most important therapeutic options to control inflammation, but these drugs may also negatively influence the development of thrombosis. Different mechanisms by which drugs are able to affect endothelium, coagulation, blood cells, and blood flow could contribute to thrombosis. Both venous and arterial thrombosis may occur during immunosuppressive therapy, but venous involvement is typically more evident, although several drugs may also enhance the atherosclerotic process.

The aim of this review is to summarize the available evidence on thromboembolism incidence and related pathogenetic mechanisms in autoimmune diseases during the treatment with the mostly used immunosuppressive drugs.

\section{Glucocorticoids}

Glucocorticoids are one of the most frequently prescribed classes of drugs around the world. It was estimated that 3.5\% of Danish population redeemed a prescription for systemic glucocorticoids in $2010 .^{23}$ In the United States, it was estimated that from 1999 to 2008 the prevalence of oral 
glucocorticoid use was $1.2 \%$, and in $28.8 \%$ of cases this drug was used for 5 years and more. ${ }^{24}$ These products are widely used in patients with different diseases of various severity, from autoimmune to neoplastic disorders and pulmonary diseases.

It has been long known that glucocorticoids (mainly above $7.5 \mathrm{mg} /$ daily) are associated with an increased risk of high cholesterol levels, hyperglycemia, hypertension, and Cushing syndrome (CS), thus promoting atherosclerosis and arterial complications. Moreover, some studies have pointed out an association between glucocorticoid use and thromboembolic events. $^{25,26}$

A multicenter case-control study performed in the Netherlands reported an incidence rate of 14.6 per 1,000 person-years of thromboembolic events in patients with endogenous CS. Moreover, these subjects were compared with those diagnosed with nonfunctioning pituitary adenoma, and both groups were treated with transsphenoidal surgery. It was found that the risk of postoperative thromboembolism was significantly greater in subjects with endogenous hypercortisolism that in controls. ${ }^{27}$

However, for exogenous glucocorticoids, data on the risk for developing thrombotic complications are sparse, and the population studied is heterogeneous and with multiple comorbidities.

In a population-based case-control study using Danish databases, Johannesdottir et $\mathrm{al}^{28}$ reported that new or present glucocorticoid users have an increased risk of VTE. The adjusted incidence rate ratio (IRR) of VTE was 3.06 and 2.31 in present and new users, respectively. Subjects who filled their most recent glucocorticoid prescription within 91 to 365 days before the index date had an IRR of 1.18, whereas in former users it was 0.94 and was not associated with VTE. The effect was strongest for new users of systemic glucocorticoids, but persisted among users of inhaled glucocorticoids and glucocorticoids acting on the intestine. The adjusted IRR increased directly with the prednisolone-equivalent cumulative dose used, reaching 1.60 for doses higher than $2 \mathrm{~g}$.

Asthma, ${ }^{29}$ hematological malignancies (e.g., acute leukemia, ${ }^{30}$ multiple myeloma ${ }^{31,32}$ ), and inflammatory bowel diseases (IBDs), ${ }^{33-35}$ all conditions with a relevant systemic inflammation, are characterized by an important thromboembolic risk, and all the available clinical studies found that corticosteroids use may increase this risk. ${ }^{36}$

Similar results were found in subjects undergoing solid organ transplantation. Up to $34 \%$ of patients undergoing solid organ transplantation may develop VTE, even if percentages vary widely (renal transplantation: 2-14\%; liver transplantation: 3-5\%; heart transplantation: $18-34 \%$; lung transplantation: $8-29 \%) .{ }^{37}$ Coagulation and fibrinolysis appeared to be impaired in kidney recipients, and Patrassi et al found that steroid use mainly determined the thromboembolic risk in these subjects. ${ }^{38}$ These subjects had increased plasminogen activator inhibitor 1 (PAI-1) levels, which normalized after steroids withdrawal. Impaired fibrinolysis was found in $83 \%$ of kidney recipients, but dropped to $16.7 \%$ when steroids were stopped. $^{39}$
Glucocorticoids are also used in autoimmune diseases, which have an increased thromboembolic risk per se, as previously described. ${ }^{40,41}$

In the Hopkins Cohort study, the risk of developing any new organ damage in SLE patients was found to be independently associated with prednisone use, and the risk was more than doubled if subjects were exposed to a mean dose of $\geq 20$ | $\mathrm{mg} /$ day compared with a mean dose of $<7.5 / \mathrm{mg} /$ day (hazard ratio $[\mathrm{HR}]=2.514 ; p<0.001$ ). The risk of developing cardiovascular damage increases with a mean prior prednisone dose of $\geq 7.5 \mid \mathrm{mg} /$ day versus $<7.5 \mid \mathrm{mg} /$ day $\quad(\mathrm{HR}=1.54$; $p=0.041) .{ }^{42}$ Previous studies found similar data, ${ }^{43}$ and high-dose corticosteroid use was also associated with CVD in SLE. ${ }^{44}$

Mainly in vitro but also clinical studies demonstrated that in CS all components of the coagulation system are variously impaired (-Fig. 1). Fibrinolytic activity is involved as decreasing levels of fibrinogen and plasminogen and increased concentrations of PAI- 1 were found in in vitro, animal, and human studies. ${ }^{45-50}$ On the other hand, increased levels of prothrombin, antithrombin, von Willebrand factor, factor VIII, factor IX, factor XI, and factor XII were reported in CS patients. ${ }^{51-53}$

Glucocorticoids act also in the control of vascular smooth muscle tone, by inducing an imbalance between vasoconstriction and vasodilatation.

Vasoconstriction is mediated by impaired regulation of production and secretion of various mediators, along with increased sensitivity and reactivity of tissues to their action. ${ }^{54}$ The synthesis and secretion of endothelin- 1 is increased by glucocorticoid administration. ${ }^{55,56}$ Hypertensive rats treated with subcutaneous injections of dexamethasone have an increased production of catecholamines, and similar results were found in other animal models as well as in human studies. ${ }^{57,58}$ Other vasoactive substances are also excessively produced, such as neuropeptide $\mathrm{Y}$, arginine, vasopressin, atrial natriuretic peptide, and angiotensinogen. ${ }^{57,59}$ Vasodilatory substances, conversely, are negatively regulated by glucocorticoids. The nitric oxide biosynthetic pathways are influenced by glucocorticoids, leading to nitric oxide deficiency. Also, prostacyclin, prostaglandin E2, and kallikrein production and activity are impaired. ${ }^{60}$

As a result of the vascular wall architecture impairment, a high prevalence of atherosclerotic plaques, increased stiffness, and intima-media thickness were demonstrated in CS subjects. $^{25}$

Moreover, the hypercoagulability in CS was recently investigated using the thrombin generation test. ${ }^{61} \mathrm{CS}$ subjects were compared not only with healthy controls, but also with patients diagnosed with metabolic syndrome. It is interesting to note that the authors concluded that the thrombin generation test confirmed the presence of impaired coagulation in CS, but results are similar to those obtained in subjects with the metabolic syndrome. This underlines the importance of other factors such as obesity, hypertension, and diabetes (typically related to hypercortisolism and dysmetabolism) in determining the overall thrombotic risk. 


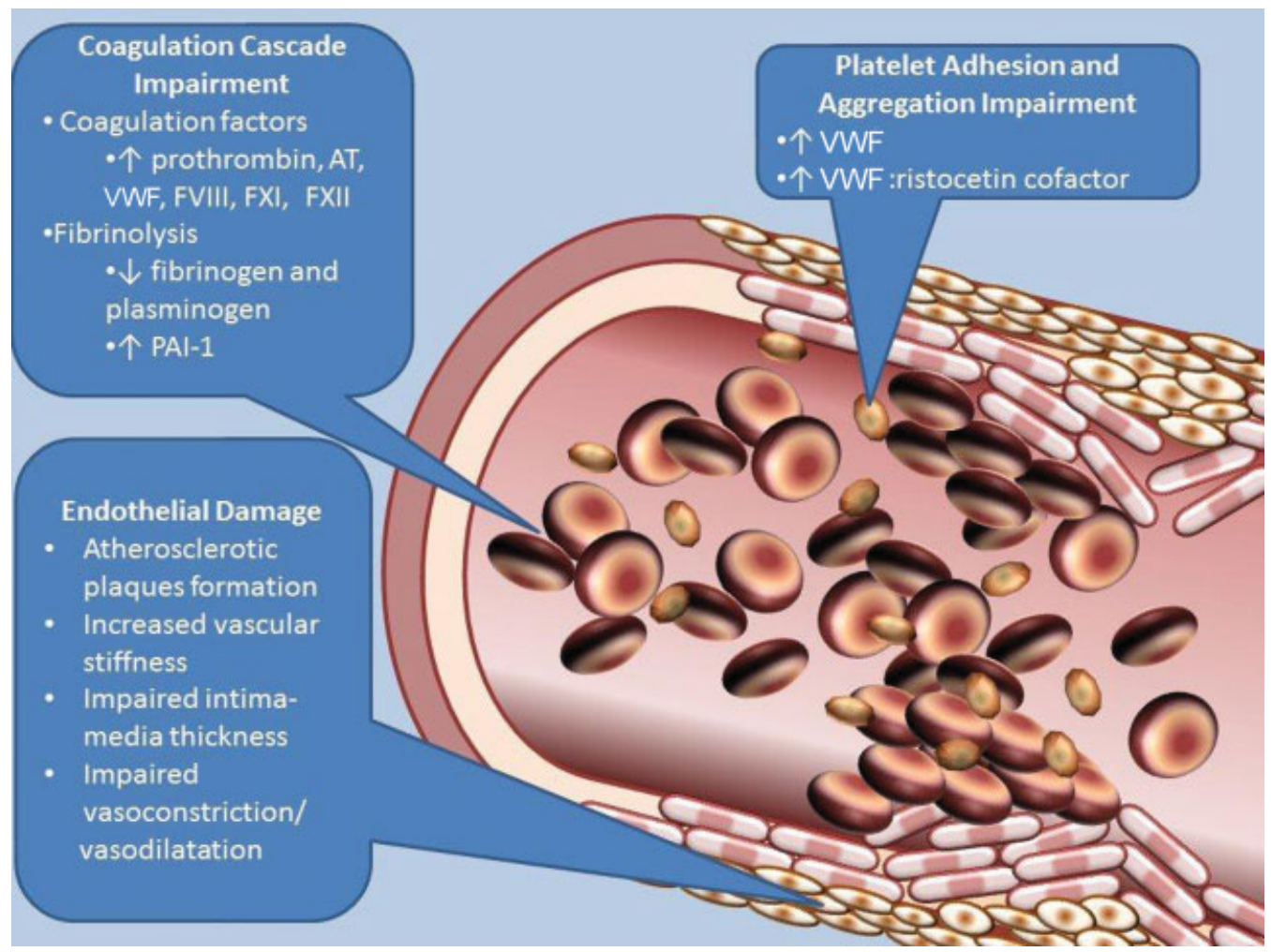

Fig. 1 Main prothrombotic mechanisms of glucocorticoids. $\uparrow$ : increased; $\downarrow$ : reduced; AT: antithrombin; VWF: von Willebrand factor; FVIII: factor VIII; FXI: factor XI; FXII: factor XII; PAI-1: plasminogen activator inhibitor-1.

\section{Intravenous Immunoglobulins}

The first case-report of a thromboembolic complication in a patient treated with IVIg was published in the $1980 \mathrm{~s}^{62}$ Over the last decades, several authors investigated the incidence of thrombotic events in subjects treated with immunoglobulins, but available studies are heterogeneous and mainly retrospective, and the populations studied vary widely. Moreover, another possible confounder is that from recent years immunoglobulins may be administered also via the subcutaneous route, ${ }^{63}$ and most recent studies include subjects treated with these preparations. The main findings in the literature on this topic are shown in - Table 1. ${ }^{64-74}$ Despite the inconclusive evidence, in 2002 the U.S. Food and Drug Administration required an updated package labeling for Ig to include a warning about the risk of thrombotic events. ${ }^{75}$

Taking into account these limitations, the reported incidence of thrombotic events varies from 3 to $13 \%{ }^{65,76}$ These events are more frequent within 24 hours after the infusion, and decrease with time. Caress et $\mathrm{al}^{77}$ in a 4 -year follow-up, analyzed a total of 498 IVIg prescriptions. Of these, 16 patients developed a stroke event, with an incidence of $0.6 \%$, within 4 days after the infusion, and in $88 \%$ of cases within 24 hours. Data from two registries ${ }^{69,71}$ supported the prothrombotic role of IVIg.

Thromboembolic events, both arterial and venous, occur more frequently in subjects with cardiovascular risk factors such as hypertension, hyperlipidemia, coronary artery disease, and diabetes mellitus. ${ }^{78}$ Rajabally and Kearney ${ }^{67}$ correlated the high incidence of early thromboembolic events with cardiovascular risk factors. In a recent case-control study, the thromboembolic risk was elevated when two or more cardiovascular risk factors were present. ${ }^{66}$ Comorbidity with hospitalization and advanced age are all factors that may increase the incidence of thrombotic events in IVIg-treated subjects ${ }^{66,67}$

Ramírez et al ${ }^{72}$ reported that also the indication for IVIg therapy may influence the thrombotic risk. Specifically, neurologic and autoimmune disease patients seem to be more affected compared with other diseases such as primary immunodeficiency syndrome and immune mediated thrombocytopenia.

Finally, the method of administration may influence the outcome. Even if comparable risks in IVIg-naïve and previously IVIg-exposed patients were found, a greater risk for a first-ever course administered was also noted, and high doses (over $35 \mathrm{~g}$ /day) may increase the thromboembolic risk. . $^{67,68,72}$

On the other hand, some authors reported contrasting data. ${ }^{79}$ The Quebec Hemovigilance System performed a retrospective review of all registered thrombosis cases in IVIgtreated patients. There were eight cases of IVIg-related thrombosis during 11 years of follow-up, with a prevalence of 0.06 cases per $100,000 \mathrm{~g}$ of IVIg given. Thus, in this population, thrombosis was not a frequent complication of IVIg therapy. ${ }^{74}$

IVIg are sometimes used in SLE and in antiphospholipid syndrome (APS) treatment. APS is a condition in which the presence of antiphospholipid antibodies is related to development of arterial and venous thromboses, and it may affect subjects with or without other autoimmune disease, particularly SLE. ${ }^{80}$ It seems that IVIg may reduce the mortality rate in 
Table 1 Main findings in studies evaluating risk factors for thromboembolic events in subjects treated with immunoglobulins

\begin{tabular}{|c|c|c|}
\hline Authors, year, and type of study & $\begin{array}{l}\text { Population studied and } \\
\text { follow-up }\end{array}$ & Main findings \\
\hline $\begin{array}{l}\text { Paran et al, }{ }^{64} 2005 \text {, retrospective } \\
\text { cohort and literature review }\end{array}$ & $\begin{array}{l}\text { Cohort: Six subjects that } \\
\text { developed TE after IVIg, } \\
\text { NR follow-up } \\
\text { Review: } 65 \text { cases of post- } \\
\text { IVIg TE }\end{array}$ & $\begin{array}{l}\text { Cohort: Six TEs (four DVTs, two SVTs). } \\
\text { Review: } 36 \text { strokes, } 13 \text { Mls, } 1 \text { stroke/MI, } 1 \text { limb ischemia, } 12 \\
\text { DVTs/PEs, } 1 \text { CVRT, } 1 \text { CSVT. Reported incidence of post-IVIg TE: } \\
0.6 \text { to 3\%. Mortality: } 20 \% \text {. } \\
\text { Patients with venous thrombosis were younger than those } \\
\text { with arterial thrombosis. } \\
\text { Risk factors: advanced age, hypertension, and coronary artery } \\
\text { disease. } \\
\text { Arterial events occurred early (within } 24 \text { h), venous events } \\
\text { occurred later (after } 24 \text { h) }\end{array}$ \\
\hline $\begin{array}{l}\text { Marie et al, }{ }^{65} 2006 \text {, retrospective } \\
\text { cohort }\end{array}$ & $\begin{array}{l}46 \text { subjects treated with } \\
\text { IVIg, } \\
\text { 2-y follow-up (2002-2004) }\end{array}$ & $\begin{array}{l}\text { Six TEs (three DVTs/PEs, two MIs, one stroke). } \\
50 \% \text { of TE occur during IVIg infusion and } 50 \% \text { within } 1 \text { to } 8 \mathrm{~d} \text {. } \\
\text { Risk factors: older age, hypertension, and } \\
\text { hypercholesterolemia }\end{array}$ \\
\hline $\begin{array}{l}\text { Caress et al, }{ }^{66} 2009 \text {, retrospective } \\
\text { case control }\end{array}$ & $\begin{array}{l}19 \text { TE compared with } 38 \\
\text { non-TE in subjects treated } \\
\text { with IVIg, } \\
\text { 6-y follow-up (1998-2004) }\end{array}$ & $\begin{array}{l}19 \text { TEs (12 strokes, } 3 \text { Mls, } 2 \text { strokes and Mls, } 1 \text { MI and DVT, } 1 \\
\text { PE). } \\
\text { Presence of four CV risk factors significantly increased TE risk. } \\
\text { Elderly and hospitalized patients are at increased risk of TE and } \\
\text { 30-d mortality }\end{array}$ \\
\hline $\begin{array}{l}\text { Rajabally and Kearney, }{ }^{67} 2011, \\
\text { retrospective cohort }\end{array}$ & $\begin{array}{l}62 \text { subjects with neuroim- } \\
\text { mune diseases, } \\
\text { 2-y follow-up (2008-2010) }\end{array}$ & $\begin{array}{l}\text { Seven TEs (two MIs, one ACS, one DVT/PE, one DVT). } \\
\text { Five of seven patients developed TE within } 14 \text { days, similar } \\
\text { incidence in naïve versus previously treated subjects. } \\
\text { Risk factors for early TE: high IVIg doses ( } \geq 35 \mathrm{~g}) \text {, immobility, } \\
\text { and presence of four or more CV risk factors }\end{array}$ \\
\hline $\begin{array}{l}\text { Huang et al, }{ }^{68} 2011, \\
\text { retrospective case control }\end{array}$ & $\begin{array}{l}67 \text { and } 22 \text { renal recipients } \\
\text { with antibody-mediated } \\
\text { rejections receiving two } \\
\text { different IVIg infusion pro- } \\
\text { tocols, } \\
5 \text {-y follow-up (2005-2010) } \\
\text { for old protocol, } 6 \text { months } \\
\text { for newer protocol }\end{array}$ & $\begin{array}{l}\text { Old protocol: Nine TEs (one NSTEMI, one RAT, one DVT, six } \\
\text { CAVFs) ( } 77.8 \% \text { occurred within } 24 \mathrm{~h} \text { ). } \\
\text { Newer protocol: no TE occurred (hydration pre- and post-IVIg; } \\
\text { routine enoxaparin and aspirin preinfusion; maximal infusion } \\
\text { rate of } 100 \mathrm{mg} / \mathrm{kg} / \mathrm{h} \text { ) }\end{array}$ \\
\hline $\begin{array}{l}\text { Daniel et al, }{ }^{69} 2012 \text {, retrospective } \\
\text { cohort (database) }\end{array}$ & $\begin{array}{l}11,785 \text { subjects treated } \\
\text { with IVIg or SClg, } \\
\text { 2-y follow-up (2008-2010) }\end{array}$ & $\begin{array}{l}122 \text { same-day TEs ( } 35 \text { arterial, } 84 \text { venous, } 3 \text { arterial and } \\
\text { venous) (I: } 10.4 \text { per } 1,000 \text { subjects) } \\
\text { Vivaglobin ( } \mathrm{SClg} \text { ) had a significant increased same-day TE risk if } \\
\text { compared with the reference IVIg product. } \\
\text { Increased TE risk was also observed with older age ( } \geq 45 \mathrm{y} \text { ), } \\
\text { prior TE events, and hypercoagulable state }\end{array}$ \\
\hline $\begin{array}{l}\text { Funk et al, }{ }^{70} 2013 \text {, retrospective } \\
\text { cohort }\end{array}$ & $\begin{array}{l}198 \text { TE subjects } \\
\text { treated with IVIg or SClg, } \\
6 \text {-y follow-up (2006-2011) }\end{array}$ & $\begin{array}{l}183 \text { IVIg TEs, of these } 100 \text { occurring within } 48 \text { h after the } \\
\text { infusion ( } 45 \text { strokes, } 24 \text { Mls, } 18 \text { PEs, } 17 \text { VTEs). } \\
29 \text { SClg TEs, } 10 \text { occurring within } 48 \text { h (6 strokes, } 3 \text { VTEs, } 1 \\
\text { Mls). } \\
\text { Overall mortality: } 32 \% \text {. } \\
\text { Risk factors: elderly, men, comorbid conditions, high doses, } \\
\text { and diuretics use. } \\
\text { During the follow-up period, TE incidence increased for Oc- } \\
\text { tagam and Vivaglobin. } \\
\text { Measuring NAPTT and TGA, an increased procoagulant was } \\
\text { demonstrated for Octagam and Vivaglobin. After changes in } \\
\text { the manufacturing process, the TE events rate decreased } \\
\text { significantly for Octagam }\end{array}$ \\
\hline $\begin{array}{l}\text { Menis et al, }{ }^{71} 2013 \text {, retrospective } \\
\text { cohort (database) }\end{array}$ & $\begin{array}{l}101,956 \text { subjects treated } \\
\text { with } \mathrm{lg}, \\
11 \text { y }(2003-2011)\end{array}$ & $\begin{array}{l}86 \text { same-day TE } \\
\text { Risk factors: age } 45 \text { y and over, hypercoagulable states, } \\
\text { history of TE, and use of products with elevated factor IX } \\
\text { activity }\end{array}$ \\
\hline $\begin{array}{l}\text { Ramírez et al, }{ }^{72} 2014, \\
\text { retrospective cohort }\end{array}$ & $\begin{array}{l}303 \text { subjects treated with } \\
\text { IVIg, } \\
\text { 2-y follow-up (2008-2010) }\end{array}$ & $\begin{array}{l}50 \text { TEs ( } 8 \text { MIs, } 5 \text { strokes, } 5 \text { CRAs, } 4 \text { CSs, } 3 \text { AAIs, } 2 \text { TIAs, } 11 \text { DVTs, } \\
7 \text { PEs, } 3 \text { IVCTs) (I: } 16.9 \% \text { ). } \\
\text { Risk factors: atrial fibrillation, coronary disease, diabetes, } \\
\text { dyslipidemia, hypertension, immobility, neoplasia, recent }\end{array}$ \\
\hline
\end{tabular}


Table 1 (Continued)

\begin{tabular}{|l|l|l|}
\hline Authors, year, and type of study & $\begin{array}{l}\text { Population studied and } \\
\text { follow-up }\end{array}$ & Main findings \\
\hline & & $\begin{array}{l}\text { surgery, SOT, and the presence of four or more CV risk factors. } \\
\text { Co-medication with diuretics, immunosuppressants, mono- } \\
\text { clonal antibodies, and prepared hematinics was significantly } \\
\text { more frequent in TE patients. } \\
\text { Arterial TE occurred after a median of } 1 \mathrm{~d}(0-20) \text { after the } \\
\text { infusion, venous after 10 d (0-27) }\end{array}$ \\
\hline $\begin{array}{l}\text { Sridhar et al, }{ }^{73} \text { 2014, } \\
\text { retrospective cohort (database) }\end{array}$ & $\begin{array}{l}14,944 \text { subjects treated } \\
\text { with IVlg or SClg, } \\
5 \text {-y follow-up (2008-2012) }\end{array}$ & $\begin{array}{l}\text { 233 (15.6 per 1,000 persons) had same-day TE (71 were } \\
\text { arterial, 157 were venous, and 5 had both). } \\
\text { Same-day TE rates varied for different Ig products ranging } \\
\text { from 0.7\% for Hizentra and up to 14.3\% for Gammaplex. An } \\
\text { increased TE risk was found with older age ( } \geq 45 \mathrm{y}), \text { prior TEs, } \\
\text { lymphoma, pulmonary circulation disorders, alcohol abuse, } \\
\text { and hypercoagulable state }\end{array}$ \\
\hline $\begin{array}{l}\text { Benadiba et al, }{ }^{74} 2015, \\
\text { retrospective cohort (database) }\end{array}$ & $\begin{array}{l}\text { NR subjects treated with } \\
\text { IVlg, } \\
11-y \text { follow-up } \\
\text { (2003-2013) }\end{array}$ & $\begin{array}{l}\text { Eight TE (three strokes, two PEs, one CSV, two DVTs). } \\
\text { The overall adult and pediatric TE rates were 0.064, 0.059, and } \\
0.168 \text { per 100,000 g of IVlg given, respectively }\end{array}$ \\
\hline
\end{tabular}

Abbreviations: AAl, acute arterial ischemia; ACS, acute coronary syndrome; CAVF, clotted arteriovenous fistula; CRA, cardiorespiratory arrest; CS, cardiogenic shock; CSVT, cerebral sinus vein thrombosis; CV, cardiovascular; CVRT, central vein retinal thrombosis; DVT, deep vein thrombosis; I, incidence; IG, immunoglobulin; IVCT, inferior vena caval thrombosis; IVIg, intravenous immunoglobulin; MI, myocardial infarction; NAPTT, nonactivated partial thromboplastin time; NR, not reported; NSTEMI, non-ST-elevation MI; PE, pulmonary embolism; RAT, renal artery thrombosis; $\mathrm{SClg}$, subcutaneous immunoglobulin; SOT, solid organ transplantation; SVT, superficial vein thrombosis; TE, thromboembolic event; TGA, thrombin generation assay; TIA, transient ischemic attack.

catastrophic APS, a rare complication of APS with multiple, life-threatening thromboses. ${ }^{81}$

It was also observed that high dose of IVIg infusion may impair platelet function as suggested in in vitro aggregometry studies. ${ }^{62,82}$ A recent study ${ }^{83}$ found that IVIg could influence platelet and monocyte activation via the ADP and TRAP-6elicited response. IVIg, particularly those associated with increased incidence of thromboembolic events, can impair FcrRII-dependent tissue factor expression in monocytes. Moreover, IVIg enhance platelet aggregation, as all IVIg lots studied contain CD154-related proteins.

IVIg can have impact on another component of the Virchow triad, that is, the vascular wall. Actually, IVIg increases blood viscosity, ${ }^{84,85}$ and seems to be able to induce arterial vasospasm ${ }^{86}$ and endothelial damage. ${ }^{87}$

Another question is about the manufacturing processes of IVIg preparations, which may contain substances with a high prothrombotic potential. High levels of anticardiolipin/antiphospholipid antibodies were found in some preparations, which could promote a thrombotic event via the development of APS. ${ }^{88}$ Wolberg et al $^{88}$ and Etscheid et $\mathrm{al}^{89}$ also found the presence of factor XIa and kallikrein in IVIg preparations. The modification of manufacturing processes and thrombogenicity testing before the release for clinical use can improve the safety of IVIg preparations, as seen for some products such as Octagam and Vivaglobin. ${ }^{70,90}$

\section{Monoclonal Antibodies}

To date, monoclonal antibodies are used in a wide range of autoimmune diseases. In a recent cohort study, that the risk of thromboembolism was found to be low in newly diagnosed RA patients, but the initiation of a therapy with monoclonal antibodies was associated with an increased short-term risk (first 180 days of follow-up), compared with disease-modifying antirheumatic drugs (DMARDS). ${ }^{91}$

Rituximab, a monoclonal anti-CD20 antibody, is used for the treatment of some oncohematological disorders such as chronic lymphocytic leukemia, low-grade or follicular lymphoma, and diffuse large B-cell lymphoma. ${ }^{92}$ Its immunomodulatory activity led to its use in some autoimmune diseases (RA, vasculitis, SLE, etc.). ${ }^{93}$ In some case reports, cardiac adverse events were correlated with rituximab infusion for oncohematological disorders, in combination with other chemotherapeutic agents. ${ }^{94,95}$ Similar data were found for autoimmune diseases, ${ }^{96,97}$ even if, recently, a large cohort study found that rates of cardiac (and stroke) events in RA subjects treated with rituximab were consistent with rates found in general RA population in an 11-year follow-up. ${ }^{98}$

Another monoclonal antibody used in RA is tocilizumab, an anti-IL-6 receptor antibody. To summarize data on the efficacy and safety of tocilizumab in RA, a recent systematic review focused on clinical studies from January 1989 to August $2011 .^{99}$ IL-6 is an important proinflammatory cytokine, involved in the pathogenesis of most systemic inflammatory diseases and also in atherosclerosis ${ }^{100}$ and coronary heart disease. ${ }^{101}$ No venous or arterial thrombotic event was reported in trials, whereas an increased level of plasma lipids was reported, even if it was reversible after an adequate lipidlowering therapy. A recent study by Ringelstein et al ${ }^{102}$ confirmed the possible role of tocilizumab impairing lipid metabolism. On a population of eight patients affected by 
active neuromyelitis optica spectrum disorder, only one developed deep vein thrombosis (DVT); however, a moderate cholesterol elevation has been observed in six of these patients.

Adalimumab, etanercept, and infliximab are the most used anti-TNF- $\alpha$ antibodies in autoimmune disorders. They were tested in psoriasis, RA, IBD, spondyloarthropathies, and vasculitis. The rationale of their use in these diseases is that TNF$\alpha$ is one of the main actors in the inflammatory cascade, initiating proinflammatory genes transcription, inducing leuko-endothelial adhesion and infiltration, and contributing to the endothelial damage. ${ }^{103,104}$ On this basis, the anti-TNF- $\alpha$ therapy should have a protective effect for the development of a thromboembolic event.

Soluble and surface CD40 ligand is overexpressed in Crohn disease, and via the modulation of CD40/CD40 ligand pathway, infliximab seems to improve the interaction between $\mathrm{T}$ lymphocytes and vessel walls and platelet activation. ${ }^{105}$ Moreover, infliximab normalizes the fibrinolytic activity, as seen in studies where it decreased the levels of prothrombin fragment $1+2$ and D-dimer, ${ }^{106}$ PAI-1, and tissue-type plasminogen activator, and improved PAI- 1 activity, ${ }^{107,108}$ thus normalizing clot lysis profile. ${ }^{109}$ A recent prospective observational cohort safety study in patients with RA showed that anti-TNF- $\alpha$ therapy is not related to any increase in the incidence of VTE events. ${ }^{110}$ Moreover, Di Minno et al ${ }^{111}$ performed a case-control study where anti-TNF- $\alpha$ therapy was compared with traditional DMARDS treatment in psoriatic arthritis. They found that TNF- $\alpha$ inhibitors significantly improved the hemostatic and fibrinolytic balance compared with DMARDS. In several case reports, thrombotic complications in BS, a variable vessel vasculitis with a high thrombotic risk, were successfully treated with TNF- $\alpha$ inhibitors. ${ }^{112-114}$

On the other hand, several authors reported that during anti-TNF- $\alpha$ therapy the production of autoantibodies, ${ }^{115}$ or the increase in the white blood count and $\operatorname{IgG}$ index (as seen in the spinal fluid of patients with multiple sclerosis treated with humanized mouse monoclonal anti-TNF- $\alpha$ antibody), ${ }^{116}$ may lead to increased viscosity. Moreover, antiphospholipid antibodies have been found during anti-TNF- $\alpha$ therapy and sometimes are associated with the development of APS. ${ }^{117-121}$

\section{Disease-Modifying Antirheumatic Drugs}

DMARDS are extensively used in different autoimmune rheumatic diseases, such as SLE and RA among them. Despite the different mechanisms of action, these drugs can reduce systemic inflammation.

With increasing interest on the role of inflammation in the pathogenesis of atherosclerotic CVD, some clinical studies assessed the potential role of anti-inflammatory agents for preventing plaque formation and progression. ${ }^{122}$ The Cardiovascular Inflammation Reduction Trial evaluates the use of low-dose methotrexate in patients with chronic atherosclerosis and diabetes mellitus or metabolic syndrome in relation to its capability to reduce the incidence of major cardiovascular events; results are expected in 2018. VTE episodes were reported during methotrexate use, especially in chemothera- py regimens. On the other hand, when used in RA subjects, methotrexate seems to be protective against thromboembolic events. $^{91}$

Recently, Belizna ${ }^{123}$ reported data on the antithrombotic activity of hydroxychloroquine in APS. This drug has antiplatelet effects and inhibits antiphospholipid antibodies binding to phospholipids surfaces. Some clinical studies confirmed that in SLE and in primary and secondary APS hydroxychloroquine can reduce the incidence of thrombotic events. $^{124,125}$

DVT has been reported during azathioprine use, but to date in only $0.55 \%$ of cases. ${ }^{126}$ On the other hand, azathioprine and its active metabolite 6-mercaptopurine are involved in the induction of warfarin resistance, as reported in some case reports. ${ }^{127}$ Pushpakom et al ${ }^{128}$ described a case of recurrent thrombosis and pulmonary embolism in a man with Crohn disease during warfarin treatment. In this case, the patient had a severe genetically determined warfarin resistance (Val66Met substitution in vitamin K epoxide reductase complex subunit 1) and international normalized ratio increased after azathioprine cessation, suggesting that this drug can have a prothrombotic effect also by interfering with warfarin metabolism.

Cyclosporine, an immunosuppressive agent that can also induce changes in endothelial cell metabolism, is involved in the pathogenesis of thrombotic microangiopathies, such as thrombotic thrombocytopenic purpura (TTP), via a dose-related direct toxicity. ${ }^{129-132}$ Indeed, cyclosporine use was related to the occurrence of nephrotoxicity and hypertension. ${ }^{133}$ Studies from our group found, and successively confirmed, that the use of cyclosporine in renal transplant is associated with increased risk of first event and recurrent VTE, both symptomatic and asymptomatic. $^{134-136}$ In addition, thrombosis of graft vessels after simultaneous pancreas and kidney transplantation seems to be less frequent when cyclosporine was replaced with tacrolimus in the immunosuppressive protocol. ${ }^{137}$

In vivo studies showed that subjects assuming cyclosporine may have an increased risk of developing VTE, particularly DVT and pulmonary embolism. ${ }^{138}$

This drug seems to activate coagulation system, because it leads to dose-dependent exposure of subendothelial matrix. ${ }^{139}$ Cyclosporine accelerates microvascular thrombus formation in vivo and it increases oxidative stress in experimental animals. ${ }^{140}$ Moreover, it leads to generation of reactive oxygen species, measured as the activities of antioxidative enzymes glutathione peroxidase, catalase, superoxide dismutase, or as malonyldialdehyde concentrations in rats. ${ }^{141}$ Platelet aggregation/secretion and thromboxane $\mathrm{A} 2$ release are also impaired by cyclosporine, and also coagulation and fibrinolytic systems may be involved. Cyclosporine, in combination with methotrexate and fluorouracil, decreases the levels of anticoagulant proteins $\mathrm{C}$ and $\mathrm{S}$ and increases PAI-1. ${ }^{142,143}$

In 2006, a review by Haddad and Greeno ${ }^{144}$ focused on the possible link between chemotherapeutic agents and thromboembolism. Cyclophosphamide is used in various chemotherapy regimens, and in the last decades, its use has been reported to be associated with an increased risk of VTE. ${ }^{145-149}$ 
Notably, it is difficult to determine the mechanism of this increase. However, cyclophosphamide was found to have a procoagulant activity in animal studies. Actually, thrombin generation is increased when acrolein, a cytochrome P metabolite, impairs the phosphatidylserine exposure and tissue factor activity. In the same study, mice treated with cyclophosphamide and acrolein had elevated plasma thrombin/ antithrombin complex levels, whereas anticoagulant protein C levels remained low. ${ }^{150}$ This drug is able to modify the microvascular architecture causing endothelial damage, ${ }^{151}$ as shown in an experimental model on liver specimens, resulting in blood stasis and thrombosis. ${ }^{152}$

In human studies, cardiotoxicity has been reported in patients treated with cyclophosphamide, and the association with methotrexate and fluorouracil chemotherapy may cause protein $\mathrm{C}$ and protein $\mathrm{S}$ deficiency along with enhanced PAI-1 levels. $^{153}$

However, the majority of studies that found a prothrombotic activity of cyclophosphamide are based on subjects with oncohematological diseases, often in combination with other immunosuppressive drugs and with other prothombotic risk factors.

Cyclophosphamide is a milestone in the treatment of autoimmune diseases and several case reports found that it might be useful in the prevention of recurrent thrombotic events in these patients. ${ }^{154-158}$

\section{Conclusion}

Different systemic autoimmune diseases are complicated by thrombotic events. ${ }^{1}$ Early atherosclerosis occurs particularly in SLE and RA, whereas both arterial and venous thrombosis are often seen in systemic vasculitis. ${ }^{17} \mathrm{BS}$ is a typical example, as it is often complicated by the occurrence of thrombotic events. ${ }^{159}$ Immunosuppressive drugs are a cornerstone in the treatment of these conditions, but, even if there is some conflicting evidence, they can impair one or more components of the Virchow triad with different mechanisms. According to the EULAR recommendations, immunosuppressive agents represent the first choice for treatment of inflammation in autoimmune diseases, and the suppression of the underlying inflammatory process might contribute to prevent thrombotic events. ${ }^{21}$ Some observational studies and case reports have reported vascular complications associated with immunosuppressive therapies. These drugs, paradoxically, may have effects on procoagulant and fibrinolytic factors, endothelium, platelet activity, and blood flow, thus leading to enhanced thrombogenesis.

To date, more evidence is available on the glucocorticoid use, as they are involved in atherosclerotic plaque formation and progression, coagulation function impairment, endothelial damage, and vascular wall dysfunction. More conflicting and partial data can be found for other drugs, such as monoclonal antibodies, endovenous immunoglobulins, and DMARDS. High-dose IVIg may also be related to thrombosis.

It is difficult, to date, to establish the clinical relevance of the prothrombotic potential of each immunomodulant drug and, above all, how physicians should choose the better immunomodulant regimen. Additional research is needed to better elucidate the mechanisms of the prothrombotic activity of these treatments, and further challenges will be required to identify the real impact of immunosuppressive agents in the onset of thrombotic events in patients with autoimmune diseases and systemic vasculitis. In the meantime, physicians should be aware of these potential risks.

\section{References}

1 Zöller B, Li X, Sundquist J, Sundquist K. Autoimmune diseases and venous thromboembolism: a review of the literature. Am J Cardiovasc Dis 2012;2(3):171-183

2 Becatti M, Emmi G, Silvestri E, et al. Neutrophil activation promotes fibrinogen oxidation and thrombus formation in Behçet's disease. Circulation 2016;133(3):302-311

3 Katz OB, Brenner B, Horowitz NA. Thrombosis in vasculitic disorders-clinical manifestations, pathogenesis and management. Thromb Res 2015;136(3):504-512

4 Margetic S. Inflammation and haemostasis. Biochem Med (Zagreb) 2012;22(1):49-62

5 Zinger H, Sherer Y, Shoenfeld Y. Atherosclerosis in autoimmune rheumatic diseases-mechanisms and clinical findings. Clin Rev Allergy Immunol 2009;37(1):20-28

6 Teixeira PC, Ferber P, Vuilleumier N, Cutler P. Biomarkers for cardiovascular risk assessment in autoimmune diseases. Proteomics Clin Appl 2015;9(1-2):48-57

7 Choy E, Ganeshalingam K, Semb AG, Szekanecz Z, Nurmohamed M. Cardiovascular risk in rheumatoid arthritis: recent advances in the understanding of the pivotal role of inflammation, risk predictors and the impact of treatment. Rheumatology (Oxford) 2014;53(12):2143-2154

8 Stojan G, Petri M. Atherosclerosis in systemic lupus erythematosus. J Cardiovasc Pharmacol 2013;62(3):255-262

9 Meesters EW, Hansen H, Spronk HM, et al. The inflammation and coagulation cross-talk in patients with systemic lupus erythematosus. Blood Coagul Fibrinolysis 2007;18(1):21-28

10 Urowitz MB, Bookman AA, Koehler BE, Gordon DA, Smythe HA Ogryzlo MA. The bimodal mortality pattern of systemic lupus erythematosus. Am J Med 1976;60(2):221-225

11 Schoenfeld SR, Kasturi S, Costenbader KH. The epidemiology of atherosclerotic cardiovascular disease among patients with SLE: a systematic review. Semin Arthritis Rheum 2013;43(1): 77-95

12 Skeoch S, Haque S, Pemberton P, Bruce IN. Cell adhesion molecules as potential biomarkers of nephritis, damage and accelerated atherosclerosis in patients with SLE. Lupus 2014;23(8): 819-824

13 Deng XL, Li XX, Liu XY, Sun L, Liu R. Comparative study on circulating endothelial progenitor cells in systemic lupus erythematosus patients at active stage. Rheumatol Int 2010;30(11): 1429-1436

14 Frieri M. Accelerated atherosclerosis in systemic lupus erythematosus: role of proinflammatory cytokines and therapeutic approaches. Curr Allergy Asthma Rep 2012;12(1):25-32

15 Skaggs BJ, Hahn BH, McMahon M. Accelerated atherosclerosis in patients with SLE-mechanisms and management. Nat Rev Rheumatol 2012;8(4):214-223

16 Soltész P, Kerekes G, Dér H, et al. Comparative assessment of vascular function in autoimmune rheumatic diseases: considerations of prevention and treatment. Autoimmun Rev 2011;10(7): 416-425

17 Emmi G, Silvestri E, Squatrito D, et al. Thrombosis in vasculitis: from pathogenesis to treatment. Thromb J 2015;13:15 
18 International Team for the Revision of the International Criteria for Behçet's Disease (ITR-ICBD). The International Criteria for Behçet's Disease (ICBD): a collaborative study of 27 countries on the sensitivity and specificity of the new criteria. J Eur Acad Dermatol Venereol 2014;28(3):338-347

19 Springer J, Villa-Forte A. Thrombosis in vasculitis. Curr Opin Rheumatol 2013;25(1):19-25

20 Niccolai E, Emmi G, Squatrito D, et al. Microparticles: bridging the gap between autoimmunity and thrombosis. Semin Thromb Hemost 2015;41(4):413-422

21 Peters MJ, Symmons DP, McCarey D, et al. EULAR evidence-based recommendations for cardiovascular risk management in patients with rheumatoid arthritis and other forms of inflammatory arthritis. Ann Rheum Dis 2010;69(2):325-331

22 Prisco D. Behçet's Syndrome: From Pathogenesis to Treatment. Series-Rare Diseases of the Immune System. Springer; 2014

23 Danish Medicines Agency. Sales of Medicinal Products within the Different ATC Groups in the Primary Healthcare Sector. Medicinal Product Statistics 2006-2010. Copenhagen: Danish Medicines Agency; 2011:80

24 Overman RA, Yeh JY, Deal CL. Prevalence of oral glucocorticoid usage in the United States: a general population perspective. Arthritis Care Res (Hoboken) 2013;65(2):294-298

25 Miljic P, Miljic D, Cain JW, Korbonits M, Popovic V. Pathogenesis of vascular complications in Cushing's syndrome. Hormones (Athens) 2012;11(1):21-30

26 Zakarija A, Kwaan HC. Adverse effects on hemostatic function of drugs used in hematologic malignancies. Semin Thromb Hemost 2007;33(4):355-364

27 Stuijver DJ, van Zaane B, Feelders RA, et al. Incidence of venous thromboembolism in patients with Cushing's syndrome: a multicenter cohort study. J Clin Endocrinol Metab 2011;96(11): 3525-3532

28 Johannesdottir SA, Horváth-Puhó E, Dekkers OM, et al. Use of glucocorticoids and risk of venous thromboembolism: a nationwide population-based case-control study. JAMA Intern Med 2013;173(9):743-752

29 Majoor CJ, Kamphuisen PW, Zwinderman AH, et al. Risk of deep vein thrombosis and pulmonary embolism in asthma. Eur Respir J 2013;42(3):655-661

30 Wun T, White RH. Venous thromboembolism in patients with acute leukemia, lymphoma, and multiple myeloma. Thromb Res 2010;125(Suppl 2):S96-S102

31 Weber DM, Chen C, Niesvizky R, et al. Multiple Myeloma (009) Study Investigators. Lenalidomide plus dexamethasone for relapsed multiple myeloma in North America. N Engl J Med 2007;357(21):2133-2142

32 Katodritou E, Vadikolia C, Lalagianni C, et al. "Real-world" data on the efficacy and safety of lenalidomide and dexamethasone in patients with relapsed/refractory multiple myeloma who were treated according to the standard clinical practice: a study of the Greek Myeloma Study Group. Ann Hematol 2014;93(1):129-139

33 Nguyen GC, Elnahas A, Jackson TD. The impact of preoperative steroid use on short-term outcomes following surgery for inflammatory bowel disease. J Crohn's Colitis 2014;8(12): 1661-1667

34 Kappelman MD, Horvath-Puho E, Sandler RS, et al. Thromboembolic risk among Danish children and adults with inflammatory bowel diseases: a population-based nationwide study. Gut 2011; 60(7):937-943

35 Giannotta M, Tapete G, Emmi G, Silvestri E, Milla M. Thrombosis in inflammatory bowel diseases: what's the link? Thromb J 2015; 13:14

36 Higgins PD, Skup M, Mulani PM, Lin J, Chao J. Increased risk of venous thromboembolic events with corticosteroid vs biologic therapy for inflammatory bowel disease. Clin Gastroenterol Hepatol 2015;13(2):316-321
37 Sáez-Giménez B, Berastegui C, Loor K, et al. Deep vein thrombosis and pulmonary embolism after solid organ transplantation: an unresolved problem. Transplant Rev (Orlando) 2015;29(2):85-92

38 Patrassi GM, Sartori MT, Rigotti P, et al. Reduced fibrinolytic potential one year after kidney transplantation. Relationship to long-term steroid treatment. Transplantation 1995;59(10): 1416-1420

39 Sartori MT, Patrassi GM, Rigotti P, et al. Improved fibrinolytic capacity after withdrawal of steroid immunosuppression in renal transplant recipients. Transplantation 2000;69(10):2116-2121

40 Peeters PJ, Bazelier MT, Uitdehaag BM, Leufkens HG, De Bruin ML, de Vries F. The risk of venous thromboembolism in patients with multiple sclerosis: the Clinical Practice Research Datalink. J Thromb Haemost 2014;12(4):444-451

41 Stassen PM, Derks RP, Kallenberg CG, Stegeman CA. Venous thromboembolism in ANCA-associated vasculitis-incidence and risk factors. Rheumatology (Oxford) 2008;47(4):530-534

42 Al Sawah S, Zhang X, Zhu B, et al. Effect of corticosteroid use by dose on the risk of developing organ damage over time in systemic lupus erythematosus-the Hopkins Lupus Cohort. Lupus Sci Med 2015;2(1):e000066

43 Calvo-Alén J, Toloza SM, Fernández M, et al; LUMINA Study Group. Systemic lupus erythematosus in a multiethnic US cohort (LUMINA). XXV. Smoking, older age, disease activity, lupus anticoagulant, and glucocorticoid dose as risk factors for the occurrence of venous thrombosis in lupus patients. Arthritis Rheum 2005;52(7):2060-2068

44 Karp I, Abrahamowicz M, Fortin PR, et al. Recent corticosteroid use and recent disease activity: independent determinants of coronary heart disease risk factors in systemic lupus erythematosus? Arthritis Rheum 2008;59(2):169-175

45 Jacoby RC, Owings JT, Ortega T, Gosselin R, Feldman EC. Biochemical basis for the hypercoagulable state seen in Cushing syndrome; discussion 1006-7. Arch Surg 2001;136(9):1003-1006

46 Fatti LM, Bottasso B, Invitti C, Coppola R, Cavagnini F, Mannucci PM. Markers of activation of coagulation and fibrinolysis in patients with Cushing's syndrome. J Endocrinol Invest 2000; 23(3):145-150

47 Patrassi GM, Sartori MT, Viero ML, Scarano L, Boscaro M, Girolami A. The fibrinolytic potential in patients with Cushing's disease: a clue to their hypercoagulable state. Blood Coagul Fibrinolysis 1992;3(6):789-793

48 Laug WE. Glucocorticoids inhibit plasminogen activator production by endothelial cells. Thromb Haemost 1983;50(4):888-892

49 Barouski-Miller PA, Gelehrter TD. Paradoxical effects of glucocorticoids on regulation of plasminogen activator activity of rat hepatoma cells. Proc Natl Acad Sci U S A 1982;79(7):2319-2322

50 Franchini M, Lippi G, Manzato F, Vescovi PP, Targher G. Hemostatic abnormalities in endocrine and metabolic disorders. Eur J Endocrinol 2010;162(3):439-451

51 Kastelan D, Dusek T, Kraljevic I, et al. Hypercoagulability in Cushing's syndrome: the role of specific haemostatic and fibrinolytic markers. Endocrine 2009;36(1):70-74

52 Casonato A, Pontara E, Boscaro M, et al. Abnormalities of von Willebrand factor are also part of the prothrombotic state of Cushing's syndrome. Blood Coagul Fibrinolysis 1999;10(3): 145-151

53 Erem C, Nuhoglu I, Yilmaz M, et al. Blood coagulation and fibrinolysis in patients with Cushing's syndrome: increased plasminogen activator inhibitor-1, decreased tissue factor pathway inhibitor, and unchanged thrombin-activatable fibrinolysis inhibitor levels. J Endocrinol Invest 2009;32(2):169-174

54 Peppa M, Krania M, Raptis SA. Hypertension and other morbidities with Cushing's syndrome associated with corticosteroids: a review. Integr Blood Press Control 2011;4:7-16

55 Roubert P, Viossat I, Lonchampt MO, et al. Endothelin receptor regulation by endothelin synthesis in vascular smooth muscle 
cells: effects of dexamethasone and phosphoramidon. J Vasc Res 1993;30(3):139-144

56 Börcsök I, Schairer HU, Sommer U, et al. Glucocorticoids regulate the expression of the human osteoblastic endothelin A receptor gene. J Exp Med 1998;188(9):1563-1573

57 Magiakou MA, Smyrnaki P, Chrousos GP. Hypertension in Cushing's syndrome. Best Pract Res Clin Endocrinol Metab 2006;20(3): 467-482

58 Kennedy B, Ziegler MG. Cardiac epinephrine synthesis. Regulation by a glucocorticoid. Circulation 1991;84(2):891-895

59 Edvinsson L, Ekblad E, Håkanson R, Wahlestedt C. Neuropeptide Y potentiates the effect of various vasoconstrictor agents on rabbit blood vessels. Br J Pharmacol 1984;83(2):519-525

60 Yang S, Zhang L. Glucocorticoids and vascular reactivity. Curr Vasc Pharmacol 2004;2(1):1-12

61 Koutroumpi S, Spiezia L, Albiger N, et al. Thrombin generation in Cushing's syndrome: do the conventional clotting indices tell the whole truth? Pituitary 2014;17(1):68-75

62 Woodruff RK, Grigg AP, Firkin FC, Smith IL. Fatal thrombotic events during treatment of autoimmune thrombocytopenia with intravenous immunoglobulin in elderly patients. Lancet 1986; 2(8500):217-218

63 Misbah S, Sturzenegger MH, Borte M, et al. Subcutaneous immunoglobulin: opportunities and outlook. Clin Exp Immunol 2009; 158(Suppl 1):51-59

64 Paran D, Herishanu Y, Elkayam O, Shopin L, Ben-Ami R. Venous and arterial thrombosis following administration of intravenous immunoglobulins. Blood Coagul Fibrinolysis 2005;16(5): 313-318

65 Marie I, Maurey G, Hervé F, Hellot MF, Levesque H. Intravenous immunoglobulin-associated arterial and venous thrombosis; report of a series and review of the literature. $\mathrm{Br} \mathrm{J}$ Dermatol 2006;155(4):714-721

66 Caress JB, Hobson-Webb L, Passmore LV, Finkbiner AP, Cartwright MS. Case-control study of thromboembolic events associated with IV immunoglobulin. J Neurol 2009;256(3):339-342

67 Rajabally YA, Kearney DA. Thromboembolic complications of intravenous immunoglobulin therapy in patients with neuropathy: a two-year study. J Neurol Sci 2011;308(1-2):124-127

68 Huang L, Kanellis J, Mulley W. Slow and steady. Reducing thrombotic events in renal transplant recipients treated with IVIg for antibody-mediated rejection. Nephrology (Carlton) 2011;16(2): 239-242

69 Daniel GW, Menis M, Sridhar G, et al. Immune globulins and thrombotic adverse events as recorded in a large administrative database in 2008 through 2010. Transfusion 2012;52(10): 2113-2121

70 Funk MB, Gross N, Gross S, et al. Thromboembolic events associated with immunoglobulin treatment. Vox Sang 2013;105(1): 54-64

71 Menis M, Sridhar G, Selvam N, et al. Hyperimmune globulins and same-day thrombotic adverse events as recorded in a large healthcare database during 2008-2011. Am J Hematol 2013; 88(12):1035-1040

72 Ramírez E, Romero-Garrido JA, López-Granados E, et al. Symptomatic thromboembolic events in patients treated with intravenous-immunoglobulins: results from a retrospective cohort study. Thromb Res 2014;133(6):1045-1051

73 Sridhar G, Ekezue BF, Izurieta HS, et al. Immune globulins and same-day thrombotic events as recorded in a large health care database during 2008 to 2012. Transfusion 2014;54(10): 2553-2565

74 Benadiba J, Robitaille N, Lambert G, Itaj NK, Pastore Y. Intravenous immunoglobulin-associated thrombosis: is it such a rare event? Report of a pediatric case and of the Quebec Hemovigilance System. Transfusion 2015;55(3):571-575

75 Dear Manufacturer: Immune Globulin Intravenous (Human) (IGIV); Required Updates to Product Labeling. Silver Spring,
MD: U.S. Food and Drug Administration; 2003. Available online at: http://www.fda.gov/biologicsbloodvaccines/safetyavailability/ucm093491.htm

76 Dalakas MC. High-dose intravenous immunoglobulin and serum viscosity: risk of precipitating thromboembolic events. Neurology $1994 ; 44(2): 223-226$

77 Caress JB, Cartwright MS, Donofrio PD, Peacock JE Jr. The clinical features of 16 cases of stroke associated with administration of IVIg. Neurology 2003;60(11):1822-1824

78 Flannery MT, Humphrey D. Deep venous thrombosis with pulmonary embolism related to IVIg treatment: a case report and literature review. Case Rep Med 2015;2015:971321

79 Basta M. Intravenous immunoglobulin-related thromboembolic events - an accusation that proves the opposite. Clin Exp Immunol 2014;178(Suppl 1):153-155

$80 \mathrm{Emmi}$ G, Silvestri E, Squatrito D, et al. An approach to differential diagnosis of antiphospholipid antibody syndrome and related conditions. ScientificWorldJournal 2014;2014:341342

81 Bayry J, Negi VS, Kaveri SV. Intravenous immunoglobulin therapy in rheumatic diseases. Nat Rev Rheumatol 2011;7(6):349-359

82 Duhem C, Dicato MA, Ries F. Side-effects of intravenous immune globulins. Clin Exp Immunol 1994;97(Suppl 1):79-83

83 Salge-Bartels U, Heiden M, Groß N, Seitz R. Significance of platelet and monocyte activation for therapeutic immunoglobulin-induced thromboembolism. Thromb Res 2014;133(2):244-253

84 Bentley P, Rosso M, Sadnicka A, Israeli-Korn S, Laffan M, Sharma P. Intravenous immunoglobulin increases plasma viscosity without parallel rise in blood pressure. J Clin Pharm Ther 2012;37(3): 286-290

85 Reinhart WH, Berchtold PE. Effect of high-dose intravenous immunoglobulin therapy on blood rheology. Lancet 1992; 339(8794):662-664

86 Sztajzel R, Le Floch-Rohr J, Eggimann P. High-dose intravenous immunoglobulin treatment and cerebral vasospasm: A possible mechanism of ischemic encephalopathy? Eur Neurol 1999;41(3): 153-158

87 Sakurai Y, Takatsuka H, Onaka M, Takada M, Nishino M. Persistent endothelial damage after intravenous immunoglobulin therapy in Kawasaki disease. Int Arch Allergy Immunol 2014;165(2): $111-118$

88 Wolberg AS, Kon RH, Monroe DM, Hoffman M. Coagulation factor $\mathrm{XI}$ is a contaminant in intravenous immunoglobulin preparations. Am J Hematol 2000;65(1):30-34

89 Etscheid M, Breitner-Ruddock S, Gross S, Hunfeld A, Seitz R, Dodt J. Identification of kallikrein and FXIa as impurities in therapeutic immunoglobulins: implications for the safety and control of intravenous blood products. Vox Sang 2012;102(1):40-46

90 Roemisch JR, Kaar W, Zoechling A, Kannicht C, Putz M, Kohla G. Identification of activated FXI as the major biochemical root cause in IVIG batches associated with thromboembolic events. Analytical and experimental approaches resulting in corrective and preventive measures implemented into the Octagam ${ }^{\circledR}$ manufacturing process. WebmedCentral Immunotherapy 2011; 2(6):WMC002002

91 Kim SC, Solomon DH, Liu J, Franklin JM, Glynn RJ, Schneeweiss S. Risk of venous thromboembolism in patients with rheumatoid arthritis: initiating disease-modifying antirheumatic drugs. Am J Med 2015;128(5):539.e7-539.e17

92 Mato A, Feldman T, Zielonka T, et al. Rituximab, cyclophosphamide-fractionated, vincristine, doxorubicin and dexamethasone alternating with rituximab, methotrexate and cytarabine overcomes risk features associated with inferior outcomes in treatment of newly diagnosed, high-risk diffuse large B-cell lymphoma. Leuk Lymphoma 2013;54(12):2606-2612

93 Iaccarino L, Bartoloni E, Carli L, et al. Efficacy and safety of offlabel use of rituximab in refractory lupus: data from the Italian Multicentre Registry. Clin Exp Rheumatol 2015;33(4): 449-456 
94 Roy A, Khanna N, Senguttuvan NB. Rituximab-vincristine chemotherapy-induced acute anterior wall myocardial infarction with cardiogenic shock. Tex Heart Inst J 2014;41(1):80-82

$95 \mathrm{Ke}$ C, Khosla A, Davis MK, Hague C, Toma M. A case of coronary vasospasm after repeat rituximab infusion. Case Rep Cardiol 2015;2015:523149

96 van Sijl AM, van der Weele W, Nurmohamed MT. Myocardial infarction after rituximab treatment for rheumatoid arthritis: is there a link? Curr Pharm Des 2014;20(4):496-499

97 Shetty S, Ahmed AR. Preliminary analysis of mortality associated with rituximab use in autoimmune diseases. Autoimmunity 2013;46(8):487-496

98 van Vollenhoven RF, Fleischmann RM, Furst DE, Lacey S, Lehane PB. Longterm safety of rituximab: final report of the Rheumatoid Arthritis Global Clinical Trial Program over 11 years. J Rheumatol 2015;42(10):1761-1766

99 Navarro-Millán I, Singh JA, Curtis JR. Systematic review of tocilizumab for rheumatoid arthritis: a new biologic agent targeting the interleukin-6 receptor. Clin Ther 2012;34(4):788-802.e3

100 Ridker PM, Lüscher TF. Anti-inflammatory therapies for cardiovascular disease. Eur Heart J 2014;35(27):1782-1791

101 Sarwar N, Butterworth AS, Freitag DF, et al; IL6R Genetics Consortium Emerging Risk Factors Collaboration. Interleukin-6 receptor pathways in coronary heart disease: a collaborative meta-analysis of 82 studies. Lancet 2012;379(9822): 1205-1213

102 Ringelstein M, Ayzenberg I, Harmel J, et al. Long-term therapy with interleukin 6 receptor blockade in highly active neuromyelitis optica spectrum disorder. JAMA Neurol 2015;72(7): 756-763

103 Tracey D, Klareskog L, Sasso EH, Salfeld JG, Tak PP. Tumor necrosis factor antagonist mechanisms of action: a comprehensive review. Pharmacol Ther 2008;117(2):244-279

104 Bacon PA. Endothelial cell dysfunction in systemic vasculitis: new developments and therapeutic prospects. Curr Opin Rheumatol 2005;17(1):49-55

105 Danese S, Sans M, Scaldaferri F, et al. TNF-alpha blockade down-regulates the CD40/CD40L pathway in the mucosal microcirculation: a novel anti-inflammatory mechanism of infliximab in Crohn's disease. J Immunol 2006;176(4): 2617-2624

106 Ingegnoli F, Fantini F, Favalli EG, et al. Inflammatory and prothrombotic biomarkers in patients with rheumatoid arthritis: effects of tumor necrosis factor-alpha blockade. J Autoimmun 2008;31(2):175-179

107 Ingegnoli F, Fantini F, Griffini S, Soldi A, Meroni PL, Cugno M. Antitumor necrosis factor alpha therapy normalizes fibrinolysis impairment in patients with active rheumatoid arthritis. Clin Exp Rheumatol 2010;28(2):254-257

108 Agirbasli M, Inanc N, Baykan OA, Direskeneli H. The effects of TNF alpha inhibition on plasma fibrinolytic balance in patients with chronic inflammatory rheumatical disorders. Clin Exp Rheumatol 2006;24(5):580-583

109 Bollen L, Vande Casteele N, Peeters M, et al. Short-term effect of infliximab is reflected in the clot lysis profile of patients with inflammatory bowel disease: a prospective study. Inflamm Bowel Dis 2015;21(3):570-578

110 Davies R, Galloway JB, Watson KD, Lunt M, Symmons DP, Hyrich KL; BSRBR Control Centre Consortium, British Society for Rheumatology Biologics Register. Venous thrombotic events are not increased in patients with rheumatoid arthritis treated with anti-TNF therapy: results from the British Society for Rheumatology Biologics Register. Ann Rheum Dis 2011;70(10): 1831-1834

111 Di Minno MN, Iervolino S, Peluso R, Di Minno A, Ambrosino P, Scarpa R; CaRRDs Study Group. Hemostatic and fibrinolytic changes are related to inflammatory conditions in patients with psoriatic arthritis-effect of different treatments. J Rheumatol 2014;41(4):714-722

112 Yoshida S, Takeuchi T, Yoshikawa A, et al. Good response to infliximab in a patient with deep vein thrombosis associated with Behçet disease. Mod Rheumatol 2012;22(5):791-795

113 Adler S, Baumgartner I, Villiger PM. Behçet's disease: successful treatment with infliximab in 7 patients with severe vascular manifestations. A retrospective analysis. Arthritis Care Res (Hoboken) 2012;64(4):607-611

114 Silvestri E, Emmi G, Prisco D. Vascular Behçet's disease: new insights in the management of thrombosis. Expert Rev Cardiovasc Ther 2013;11(12):1583-1585

115 Ferraccioli G, Gremese E. Thrombogenicity of TNF alpha in rheumatoid arthritis defined through biological probes: TNF alpha blockers. Autoimmun Rev 2004;3(4):261-266

116 van Oosten BW, Barkhof F, Truyen L, et al. Increased MRI activity and immune activation in two multiple sclerosis patients treated with the monoclonal anti-tumor necrosis factor antibody cA2. Neurology 1996;47(6):1531-1534

117 Nosbaum A, Goujon C, Fleury B, Guillot I, Nicolas JF, Bérard F. Arterial thrombosis with anti-phospholipid antibodies induced by infliximab. Eur J Dermatol 2007;17(6):546-547

118 Vereckei E, Kriván G, Réti M, Szodoray P, Poór G, Kiss E. Anti-TNFalpha-induced anti-phospholipid syndrome manifested as necrotizing vasculitis. Scand J Rheumatol 2010;39(2):175-177

119 Puli SR, Benage DD. Retinal vein thrombosis after infliximab (Remicade) treatment for Crohn's disease. Am J Gastroenterol 2003;98(4):939-940

120 Virupannavar S, Brandau A, Guggenheim C, Laird-Fick H. Possible association of etanercept, venous thrombosis, and induction of antiphospholipid syndrome. Case Rep Rheumatol 2014; 2014:801072

121 Hemmati I, Kur J. Adalimumab-associated antiphospholipid syndrome: a case report and review of the literature. Clin Rheumatol 2013;32(7):1095-1098

122 Yamashita T, Sasaki N, Kasahara K, Hirata K. Anti-inflammatory and immune-modulatory therapies for preventing atherosclerotic cardiovascular disease. J Cardiol 2015;66(1):1-8

123 Belizna C. Hydroxychloroquine as an anti-thrombotic in antiphospholipid syndrome. Autoimmun Rev 2015;14(4): 358-362

124 Petri M. Use of hydroxychloroquine to prevent thrombosis in systemic lupus erythematosus and in antiphospholipid antibodypositive patients. Curr Rheumatol Rep 2011;13(1):77-80

125 Erkan D, Aguiar CL, Andrade D, et al. 14th International Congress on Antiphospholipid Antibodies: task force report on antiphospholipid syndrome treatment trends. Autoimmun Rev 2014; 13(6):685-696

126 Review: could Azathioprine cause Dvt (Deep venous thrombosis)? Available online at: http://www.ehealthme.com/print/ ds14570451. Accessed December 3, 2015

127 Vazquez SR, Rondina MT, Pendleton RC. Azathioprine-induced warfarin resistance. Ann Pharmacother 2008;42(7): $1118-1123$

128 Pushpakom SP, Gambhir N, Latif A, Hadfield KD, Campbell S, Newman WG. Exacerbation of hereditary warfarin resistance by azathioprine. Clin Appl Thromb Hemost 2011;17(3): 293-296

129 Ödek Ç, Kendirli T, Yaman A, Ileri T, Kuloğlu Z, Ince E. Cyclosporine-associated thrombotic microangiopathy and thrombocytopenia-associated multiple organ failure: a case successfully treated with therapeutic plasma exchange. J Pediatr Hematol Oncol 2014;36(2):e88-e90

130 Elliott MA, Nichols WL Jr, Plumhoff EA, et al. Posttransplantation thrombotic thrombocytopenic purpura: a single-center experience and a contemporary review. Mayo Clin Proc 2003;78(4): 421-430 
131 Andersohn F, Bronder E, Klimpel A, Garbe E. Proportion of drugrelated serious rare blood dyscrasias: estimates from the Berlin CaseControl Surveillance Study. Am J Hematol 2004;77(3):316-318

132 Medina PJ, Sipols JM, George JN. Drug-associated thrombotic thrombocytopenic purpura-hemolytic uremic syndrome. Curr Opin Hematol 2001;8(5):286-293

133 Zarifian A, Meleg-Smith S, O'donovan R, Tesi RJ, Batuman V. Cyclosporine-associated thrombotic microangiopathy in renal allografts. Kidney Int 1999;55(6):2457-2466

134 Poli D, Zanazzi M, Antonucci E, et al. Renal transplant recipients are at high risk for both symptomatic and asymptomatic deep vein thrombosis. J Thromb Haemost 2006;4(5):988-992

135 Poli D, Zanazzi M, Antonucci E, et al. High rate of recurrence in renal transplant recipients after a first episode of venous thromboembolism. Transplantation 2005;80(6):789-793

136 Zanazzi M, Poli D, Antonucci E, et al. Venous thromboembolism in renal transplant recipients: high rate of recurrence. Transplant Proc 2005;37(6):2493-2494

137 Steurer W, Malaise J, Mark W, Koenigsrainer A, Margreiter R; Euro-SPK Study Group. Spectrum of surgical complications after simultaneous pancreas-kidney transplantation in a prospectively randomized study of two immunosuppressive protocols. Nephrol Dial Transplant 2005;20(Suppl 2):ii54-ii62

138 Vanrenterghem Y, Roels L, Lerut T, et al. Thromboembolic complications and haemostatic changes in cyclosporin-treated cadaveric kidney allograft recipients. Lancet 1985;1(8436): 999-1002

139 Bombeli T, Müller M, Straub PW, Haeberli A. Cyclosporineinduced detachment of vascular endothelial cells initiates the intrinsic coagulation system in plasma and whole blood.J Lab Clin Med 1996;127(6):621-634

140 Püschel A, Lindenblatt N, Katzfuss J, Vollmar B, Klar E. Immunosuppressants accelerate microvascular thrombus formation in vivo: role of endothelial cell activation. Surgery 2012;151(1): 26-36

141 Kedzierska K, Sporniak-Tutak K, Bober J, et al. Oxidative stress indices in rats under immunosuppression. Transplant Proc 2011; 43(10):3939-3945

142 Grace AA, Barradas MA, Mikhailidis DP, et al. Cyclosporine A enhances platelet aggregation. Kidney Int 1987;32(6):889-895

143 Naik UP, Markell M, Ehrlich YH, Kornecki E. Cyclosporine A enhances agonist-induced aggregation of human platelets by stimulating protein phosphorylation. Cell Mol Biol Res 1993; 39(3):257-264

144 Haddad TC, Greeno EW. Chemotherapy-induced thrombosis. Thromb Res 2006;118(5):555-568

145 Kansu E. Thrombosis in stem cell transplantation. Hematology 2012;17(Suppl 1):S159-S162

146 Mukherjee SD, Swystun LL, Mackman N, et al. Impact of chemotherapy on thrombin generation and on the protein $C$ pathway in breast cancer patients. Pathophysiol Haemost Thromb 2010; 37(2-4):88-97
147 Kessler P, Pour L, Gregora E, et al; Czech Myeloma Group. Low molecular weight heparins for thromboprophylaxis during induction chemotherapy in patients with multiple myeloma. Klin Onkol 2011;24(4):281-286

148 Ganjoo K, Hong F, Horning SJ, et al. Bevacizumab and cyclosphosphamide, doxorubicin, vincristine and prednisone in combination for patients with peripheral T-cell or natural killer cell neoplasms: an Eastern Cooperative Oncology Group study (E2404). Leuk Lymphoma 2014;55(4):768-772

149 Khorana AA, Francis CW, Culakova E, Kuderer NM, Lyman GH. Frequency, risk factors, and trends for venous thromboembolism among hospitalized cancer patients. Cancer 2007;110(10): 2339-2346

150 Swystun LL, Mukherjee S, Levine M, Liaw PC. The chemotherapy metabolite acrolein upregulates thrombin generation and impairs the protein $C$ anticoagulant pathway in animalbased and cell-based models. J Thromb Haemost 2011;9(4): 767-775

151 Zeng L, Yan Z, Ding S, Xu K, Wang L. Endothelial injury, an intriguing effect of methotrexate and cyclophosphamide during hematopoietic stem cell transplantation in mice. Transplant Proc 2008;40(8):2670-2673

152 Nepomnyashchikh LM, Molodykh OP, Lushnikova EL, Sorokina YA. Morphogenesis and histostereological analysis of hepatopathy induced by cyclophosphamide. Bull Exp Biol Med 2010; 149(1):104-112

153 Rella C, Coviello M, Giotta F, et al. A prothrombotic state in breast cancer patients treated with adjuvant chemotherapy. Breast Cancer Res Treat 1996;40(2):151-159

154 Ajmani S, Misra DP, Raja DC, Mohindra N, Agarwal V. Behcet's disease with intracardiac thrombus presenting with fever of unknown etiology. Case Reports Immunol 2015; 2015:149359

155 Tascilar NF, Akman-Demir G, Demiryurek BE, Tokgoz O, Akgun $\mathrm{N}$, Ozen Barut B. An unusual case of neuro-Behçet's disease presenting with co-occurence of cerebral venous sinus thrombosis with basilar artery occlusion. Neurol Sci 2013;34(5): 785-788

156 Düzgün N, Küçükşahin O, Atasoy KÇ, et al. Behçet's disease and intracardiac thrombosis: a report of three cases. Case Rep Rheumatol 2013;2013:637015

157 Tseng ST, Tseng MH, Huang JL. Concurrent pulmonary hemorrhage and deep vein thrombosis in a child with ANCA-associated vasculitis: case report and review of literature. Pediatr Rheumatol Online J 2015;13:20

158 Emmungil H, Yaşar Bilge NŞ, Küçükşahin O, et al. A rare but serious manifestation of Behçet's disease: intracardiac thrombus in 22 patients. Clin Exp Rheumatol 2014;32(4, Suppl 84): S87-S92

159 Desbois AC, Wechsler B, Resche-Rigon M, et al. Immunosuppressants reduce venous thrombosis relapse in Behçet's disease. Arthritis Rheum 2012;64(8):2753-2760 